\title{
СУТНІСТЬ ТА СПЕЦИФІКА ПІДГОТОВКИ ЖІНКИ ДО ДУХОВНО- МОРАЛЬНОГО ВИХОВАННЯ ДІТЕЙ (НА ОСНОВІ ПРАЦЬ СВЯТИТЕЛЯ ФАДДЕЯ УСПЕНСЬКОГО)
}

У ХІХ ст. питання про зміст жіночої освіти було важливою частиною дискусій не лише про призначення жінки, а ци про жіночий інтелект. Потрібно було пройти довгий шлях від найдавніших часів $i$ до сьогодення, щоб здійснити зміни у свідомості суспільства на жіночу освіту. Міф про неспроможність жінки вирішувати важливі суспільні та життєві проблеми, опанувати знання та професійні навички розвіявся як марево. Питання жіночої освіти досить швидко посіло особливе місие в духовноосвітній політиці. Цьому, безсумнівно, сприяла та обставина, щяо духовенство здавна відчувало потребу в освіті жіночої половини населення $i$ ия освіта, на їхню думку, повинна мати свої особливості, закономірності, $i$ бути зорієнтована, передусім, на формування й набуття жінками настанов, педагогічних знань $i$ вмінь, необхідних для належного духовно-морального виховання дітей. В даній статті розкриті і проаналізовані погляди великого подвижника православ'я святителя Фаддея Успенського на підготовку жінки до духовно-морального виховання дітей. Здійснено науковотеоретичне обтрунтування сутності $i$ специфіки духовно-морального виховання у спадщині святителя.

Педагогічні погляди та переконання архієпископа Фаддея багато в чому приниипово відмінні від наріжних положень атеїстичної педагогіки та свідчать, наскільки великою $і$ навіть трагічною за своїми руйнівними наслідками виявилася втрата иіннісної орієнтації педагогічної думки, щчо базувалася на духовності та православній вірі. Однозначно, повернення педагогічної спадщини архієпископа Фаддея (Успенського) в скарбнищю нашої педагогіки відчутно збагатило б останню: осмислена з точки зору сучасних виховних проблем, вона може позитивно впливати на їхне практичне вирішення, особливо в изарині підготовки сучасних жінок до духовно-морального виховання дітей.Лише християнське виховання жінки може дати ї дитині повноцінне щастя, так як абсолютно відповідає людському єству. "Якщо багато педагогів стверджують, щзо виховання зобов'язане бути гуманним, то хто може бути гуманнішим християнина, який пройнятий любов'ю до всіх людей, як до братів у Христі, - не говорячи 
вже про те, щуо лише християнство може навчити істинної любові до всіх людей, не виключаючи ворогів»

Ключові слова: жіноча освіта, духовно-моральне виховання, православна педагогіка.

Fazan T. P. The essence and specifics of preparing a woman for spiritual and moral education of children (based on the works of saint Faddey Uspensky). In the XIX century the question of the content of women's education was an important part of the discussions not only about the purpose of women, but also about women's intelligence. It took a long way from ancient times to the present to make changes in society's consciousness for women's education. The myth of a woman's inability to solve important social and life problems, to acquire knowledge and professional skills has dissipated like a ghost. The issue of women's education quickly took a special place in spiritual and educational policy. Undoubtedly, this was facilitated by the fact that the clergy has long felt the need for education of the female half of the population and this education, in their opinion, should have its own features, patterns, and be focused primarily on the formation and acquisition of guidelines, pedagogical knowledge and skills necessary for the proper spiritual and moral education of children.This article reveals and analyzes the views of the great devotee of Orthodoxy, St. Thaddeus of the Assumption, on the preparation of women for the spiritual and moral upbringing of children. The scientific-theoretical substantiation of the essence and specifics of spiritual and moral education in the heritage of the saint is carried out.

An archbishop Thaddeus's pedagogical ideas and beliefs are fundamentally different from the cornerstones of atheistic pedagogy and show how great and even tragic the devastating consequences of the loss of the value orientation of the pedagogical thought based on spirituality and the Orthodox faith have been. Definitely, pedagogical treasury would be significantly enriched by the return of the pedagogical heritage of the archbishop Thaddeus (Uspenskyi). It can positively affect practical solution of current educational problems, especially in preparing modern women for spiritual and moral education of children. Only a Christian upbringing of a woman can give her child full happiness, as it is absolutely in line with human nature. A large number of educators rightly say that education must be humane. Who can be more humane than a Christian who is imbued with love for all people as like for the brothers in Christ, not to mention that only Christianity can teach true love for all people including enemies.

Keywords: women's education, spiritual and moral education, Orthodox pedagogy.

Вступ. Провідною метою виховання молодого покоління в українському суспільстві виступає виховання гармонійно розвиненої та суспільно активної особистості, яка володіє науковим світоглядом, має високоморальний потенціал, бажає та вміє працювати, є духовно багатою та добре розвиненою 
фізично, прагне до досконалості. Реалізація окресленої мети відбувалася під впливом багатьох чинників, котрі були провідними в різні часи.

Аналіз науково-педагогічних джерел свідчить, що в XIX столітті освіта жінок мала свою специфіку та була спрямована насамперед на духовноморальне виховання молодого покоління. Специфічними рисами підготовки жінок до реалізації зазначеного виховання дітей у XIX столітті виступали: домінування виховної мети над дидактичною; вивчення більшої кількості предметів духовного циклу, а не природничоматематичного; встановлення тісного зв'язку між школою та монастирем; організація виховання 3 використанням принципів Православ'я та народності; постійна духовна праця вихованок, яка передбачала тісне поєднання праці та освіти; використання основних положень «християнської психології»; побудова методики викладання педагогічних положень на спадщині як вітчизняних світських, так і церковних педагогів (Faddej, 1902).

Аналіз сучасних досліджень і публікацій дозволяє констатувати, щовивчення педагогічної спадщини архієпископа Фаддея носить фрагментарний характер. В основному це праці, присвячені життю та діяльності Фаддея (Успенського) (Дамаскін (Орловський), А. Плюснин, А. Ратиня, Е. Тіміряєв та інші). Однак у роботах цих авторів не розглядалися особливості освітньо-просвітницької діяльності святителя, не було обгрунтовано значення його спадщини для розробки теорії навчання й виховання. В останні роки в педагогічній періодиці почали з'являтися праці, присвячені аналізу педагогічної спадщини та освітньої діяльності Фаддея (Успенського) (Б. Жулковський, Г. Агафонова, К. Гринько, М. Сгорова, Т. Ковирзіна та інші), але спеціальне дослідження, присвячене вивченню суті та особливостей підготовки жінки до духовно-морального виховання дітей в педагогічній теорії та практиці Фаддея (Успенського) до цього часу не було проведено.

Мета та завдання. Мета статmі полягає в теоретичному аналізі та узагальненні практичної спадщини архієпископа Фаддея (Успенського) щодо підготовки жінок до духовно-морального виховання дітей у XIX столітті.

Методи дослідження. У процесі наукового пошуку використані, як загальнонаукові, так і історико-педагогічні методи наукового пізнання, котрі уможливили цілісний, об'єктивний аналіз змісту та специфіки підготовки жінок до духовно-морального виховання дітей означеної доби на основі праць святителя Фаддея Успенського.

Результати. Архієпископ Фаддей (І. Успенський; 1872-1937рp.) прожив дуже непросте, сповнене поневірянь і подвижництва, життя, що закінчилося мученицькою смертю в казематах радянського НКВС. Він походив із багатодітної священицької родини, що, однозначно, визначило 
його життєвий вибір і проявило неабияку схильність до педагогіки - як турботи про підростаюче покоління.Сам майбутній святитель отримав грунтовну духовну освіту, а в 1896 році, прийняв чернечий постриг з ім'ям Фаддей. 3 часом він захистив дисертацію й отримав ступінь магістра богослов'я, викладав у семінарії, на педагогічних курсах для вчителів церковнопарафіяльних шкіл.

Результатом його діяльності стала праця «Записки 3 дидактики», в якій він виклав власні погляди на педагогіку. На його думку, «Записки...» не $є$ цілісним курсом із педагогіки та дидактики, але в них розглянуто найважливіші питання організації освітньої діяльності в церковнопарафіяльній школі. Основне своє завдання автор убачав у тому, щоб допомогти вчителям розібратися в різноманітті теорій і поглядів на освіту та виховання, навчити їх свідомо робити свою справу.

Під вихованням Фаддей убачав розвиток сил дитини. Враховуючи відмінність цих сил і виходячи з різноманіття цілей, він говорив про різні види виховання. Так, за його твердим переконанням, існує фізичне (тілесне) виховання, метою якого виступає зміцнення тіла та його здоров'я, розвиток витривалості, легкість рухів. А під духовним вихованням (вихованням душі) він розумів розвиток розумових сил учня, яке, в свою чергу, поділяється на виховання розуму (розумове), виховання серця і виховання волі (Faddej, 1902).

Його праця «Записки 3 дидактики» стала великим помічником у виховній діяльності педагогів, оскільки в ній чітко визначено завдання, що стояли перед православним вихованням учнів. Будучи вчителем 3 великої літери, архієпископ Фаддей багато часу i сил поклав на підвищення освітнього рівня самих педагогів та на вдосконалення навчальних програм для церковнопарафіяльних і світських шкіл Міністерства народної освіти. Поліпшення методики викладання церковнослов'янської та російської мови, загальна дидактика, арифметика, церковний спів, природознавство, експериментальна психологія, сільське господарство, гігієна, шкільне будівництво - такою широкою була сфера застосування його зусиль і знань.

Він постійно працював над питанням вдосконалення навчання та виховання, шукаючи й обмірковуючи різні шляхи і підходи, методи і засоби, які б мали в собі «живу душу» і робили вчителювання більш осмисленим та результативним. У названій праці та інших «записках» архієпископа Фаддея на цю тему міститься розроблений ним дидактичний матеріал, його поради щодо прийомів та способів викладання, які покликані полегшити як учительську, так і учнівську працю, оптимізувати час, необхідний для подачі та засвоєння навчальних дисциплін. Зауважимо, що всього цього потребує і сучасний педагог. 
Свої погляди у святителя Фаддея були i на освіту жінок та їхню підготовку до подвижництва на учительській та материнській ниві, а саме - при підготовці дітей до духовно-морального виховання. Він радив їм вивчати освітню справу як теоретично, так і практично, однак не покладатися тільки на власний досвід: багаторічні спостереження навіть досвідченого вчителя i вироблені на їх основі прийоми викладання можуть стати одноманітними, а відтак - мертвими. Тому він рекомендував потенційним і практикуючим учителькам більш часто звертатися до педагогічної літератури, зокрема до творів богословів та педагогів (Faddej, 2003).

Будучи православним наставником, архієпископ Фаддей закономірно великого значення у справі народної освіти надавав творам святих отців. Духом православ'я сповнені всі педагогічні теми, над якими працював архієпископ. Так, він писав про: обов'язок учителя не лише вчити, а й виховувати дітей; поняття «виховання» i його види;щастя i користь вихованця як основну мету виховання; природовідповідність і гуманність виховання; наслідки відходу виховання від релігії; християнське виховання як єдино правильне і відповідне людській природі; обов'язок шкільного вчителя не лише вчити, а й виховувати дітей у дусі християнського благочестя (Faddej, 2003).

У своїй педагогічній концепції він виходив з твердого переконання, що вища мета і обов'язок учителя як просвітника народу - мати Христову віру для підготовки кожної ввіреної йому дитячої душі до «оселення» в ній «світла вічного і істинного». Архієпископ уважав, що найміцніша основа життя суспільства та держави створюється діяльністю вчителя.

Спираючись на традиції Святих Отців, педагог Фаддей стверджував: якщо всі турботи вихователя спрямувати тільки на вивчення наук, розвиток душевних (духовних) здібностей дитини буде однобоким. Більше того, розвиток тільки розуму шкідливо позначиться на розвитку добрих якостей серця і правильному формуванні волі. А тим часом, розвиток останніх, на думку святителя, є більш важливим за розумовий: людину цінують не стільки за iii розум та знання, скільки за добре серце або тверду волю та характер (Faddej, 1902).

Узагальнюючи погляди вітчизняних та зарубіжних педагогів, Фаддей акцентував увагу на одній небезпечній помилці, а саме - на твердженні, що виховання має розвивати тільки природні сили людини і може здійснюватися незалежно від релігії. На його думку, єдино правильним і відповідним людській природі є тільки християнське виховання: «Тільки християнство вказує для виховання мету найбільш правильну, високу і відповідну природі людини. 
Головна мета християнства полягає саме в тому, щоб перевиховати людину (Faddej, 1902).

Високі вимоги святитель висував до особистості вчителя, до його моральних якостей, оскільки вважав, що вчитель має справу з душею дитини, а отже, щоб впливати на душу, він сам повинен мати ті якості, які хоче виховати в своїх підопічних. Наголошував, що духовно-моральне обличчя вчителя (вчительки) являє учням найпереконливіший приклад життя. Владика Фаддей прагнув уберегти і захистити це «обличчя» від згубного впливу «духу століття». Він навчав учителів бачити і розуміти протилежність «між Духом Христовим і духом світу цього», який захопився гаслом насильства нібито для досягнення примарних цілей - «свободи, рівності та братерства». Не насильством слід сприяти впровадженню на землі загального блага $\mathrm{i}$ щастя, - повторював архієпископ Фаддей, - а шляхом кротості, любові та самовіддачі.

Формулюючи вимоги до духовно-моральних якостей учителя, які вони згодом передадуть своїм вихованцям, святитель розглядав покликання, духовну відданість своїй справі як основну і непорушну умову його плідної праці. Завдання вчителя полягає не тільки в тому, щоб навчити дитину читати, писати, рахувати, - це перший необхідний ступінь. Однак важливо дитину ще й виховати. Дитячі серця - це як земля, що приймає насіння. Вчитель виконає своє покликання і досягне успіху тільки в тому випадку, якщо вкладе в дитячу душу усвідомлення не лише людських чеснот, а й християнських, тобто приведе свого вихованця до Христа.

Розумова просвіта приносить користь тільки тоді, коли досягає найпотаємніших порухів душі, і тільки християнське виховання об'єднує в собі все те, до чого прагнуть викладачі та вихователі. Це положення владика Фаддей підтверджує думками великого педагога К. Ушинського, який писав, що вся вітчизняна педагогіка виросла на християнському грунті (Ushins'kij, 1971). 3 огляду на це, архієпископ Фаддей величезного значення надавав якостям, які повинен мати кожен учитель, 3 чого випливає, що він зобов'язаний не лише виховувати дітей, а й постійно вдосконалюватися сам.

Комплексному підходу до вирішення цього надзавдання служить ціла низка пунктів, розроблених Фаддеєм, як-от: про необхідність підготовки до вчительства шляхом практичним і теоретичним; про необхідність для вчителя спостережливості та вміння пристосовуватися до вихованців 3 урахуванням їхніх темпераментів; про значення особистості вчителя та його моральних якостей у навчально-виховній справі, а також важливість його зовнішнього вигляду; про покликання і сумлінність учителя; про любов до дітей i недостатність лише природної симпатії, а також привітність у 


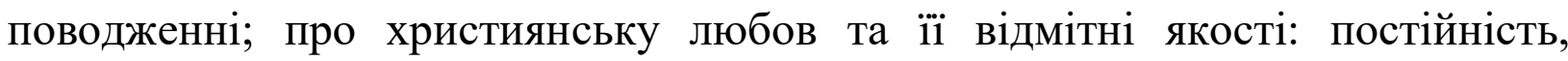
терпіння, самовіддача; про релігійну віру вчителя та справедливість; про ставлення вчителя до батьків учнів і до завідувача школи (Faddej, 2003).

Передусім, на його думку, людині, яка вирішила присвятити себе вихованню підростаючого покоління, слід читати твори i посібники 3 педагогіки та дидактики 3 методикою, а також вивчати історію педагогіки, тобто цікавитися науками, які безпосередньо стосуються справи виховання i навчання. 3 учених-педагогів святитель рекомендував звертатися до праць К. Ушинського, С. Рачинського, М. Ільминського, С. Миропольського, П. Каптерева, барона Корфа, архієпископа Амвросія Харківського та інших.

Він уважав, що на особливу увагу вчителів заслуговують також збірка О. Анастасієва «Народна школа» і праці К. Побєдоносцева «Учіння та учитель», «Історія дитячої души», «Нова школа» та ін. На думку Фаддея, у Л. Толстого також є чимало корисних поглядів на виховання, але вони однобокі й надто своєрідні. Святитель рекомендував також педагогічні журнали, що видавалися в Росії, а також праці Я. Коменського і Й. Песталоцці, тоді як твори Ж.-Ж. Руссо, Г. Спенсера, А. Бена та низку інших праць уважав шкідливими: «Без шкоди для справи вчителеві нашої школи можна за них і не братися» (Nechaev, 1917). На думку святителя, філософські переконання, які лежать в основі педагогічних поглядів цих авторів, роблять їхні твори такими, що абсолютно не відповідають здоровим християнським поглядам на виховання і навчання.

Відводячи вихованню виключно важливе місце в освітній системі, Фаддей висловив багато думок і суджень про це поняття, його види, завдання та недоліки. Він відкидав те виховання, яке ставить за мету щастя або користь вихованця. Щастя, на його думку, є недосяжним, якщо його шукають у земних благах, якщо в його основу покладено самолюбство, егоїзм. Так само і користь, якщо вона розуміється як уміння пристосовуватися до навколишнього світу, не може бути визнана метою виховання, адже за самою суттю таке прагнення приречене на невдачу: не може пристосуватися до незалежних від неї обставин людина, яка має розлад у власній душі, в самому осередку свого життя як особистості.

На думку святителя, з релігійного навчання повинно бути викинуто все, що може порушувати в дітях почуття страху і зневіри. Бог $є$ любов нехай же в дитячій душі складаються почуття, викликані тільки цим уявленням про Бога. Але так могло бути тільки в тому випадку, зауважує святитель, якби природа людська була досконала, якби вона не вимагала постійного приборкання, яким і служить почуття страху. Слід зауважити, продовжує Фаддей свої міркування, що хоча страх Божий $\epsilon$ «початок премудрості», але це не виключає, а навпаки, передбачає розвиток в серцях 
дітей почуття любові до Бога. Самий страх повинен виникнути з любові до Бога, виникати з боязні образити Бога як люблячого Отця.

Святитель Фаддей висловив цілу низку міркувань і щодо загальних якостей навчання, і стосовно конкретних методів у роботі викладача, наголошуючи, зокрема, на: природовідповідності та наочності навчання; необхідності формування в учнях самостійності; порядку, послідовності та методичності; впливі на всі пізнавальні та душевні сили учня, а також на тому, як позначається на результативності навчального процесу особистість учителя. Архієпископ не оминув увагою навіть такі «дрібнички» педагогічної майстерності, як вживання двох основних форм навчання - розповідної та питально-відповідної. Акцентуючи на слові як універсальному методі навчання та виховання, Фаддей уважав обов'язковим і контроль учителя за роботою та поведінкою учня(Faddej, 2003).

Архієпископ Фаддей уважав згубним для православного виховання беззастережне застосування гасла про «права людини», вказуючи на невизначеність самого цього поняття, що нівелює корінну відмінність життя людини від життя тварини, якій не притаманний вищий моральний закон. Тому особливого значення він надавав дисципліні, без якої досягти успіху в учительській справі неможливо. Фаддей розглянув низку аспектів цього виховного чинника, а саме: поняття про дисципліну, іï значення та засоби підтримки; різні погляди на дисципліну та їхні крайнощі. Звертаючи увагу й на інші, на його думку, - другорядні навчально-виховні засоби, він висловився, зокрема, про нагороди і покарання учнів, про теорію так званих природних покарань, про тілесні покарання і навіть про доцільну пересадку школярів (Faddej, 2003). Також він нагадував про важливість самостійної роботи учнів та спостереження за ними поза школою і звертав увагу своїх православних колег на спосіб постановки самостійних завдань та їхню перевірку, на те, як слід проводити одночасне заняття 3 двома чи трьома відділеннями, на контроль за самостійним читанням учнів та за їхньою поведінкою за межами школи і навіть на зв'язок школи зі своїми колишніми вихованцями.

Обговорення. Проведене дослідження свідчить, що зазначений досвід може бути корисним при визначенні змісту сучасної православної освіти. Педагог відшукає тут все необхідне, близьке йому за духом, котре зберегло традиції, християнське визначення завдань виховання, особливості побудови педагогічної теорії. Саме головне, про що необхідно пам'ятати - це про те, що справжня моральність не може існувати без релігійної основи, без церковної допомоги, без молитви. Життя людини не обмежується тільки земним перебуванням. Виходячи 3 цього, виховання дитини повинно 180 
допомогти їй постійно пам’ятати про цю основну мету та надати знання, як іiі досягти.

Висновки. Отже, педагогічні погляди та переконання архієпископа Фаддея багато в чому принципово відмінні від наріжних положень атеїстичної педагогіки та свідчать, наскільки великою і навіть трагічною за своїми руйнівними наслідками виявилася втрата ціннісної орієнтації педагогічної думки, що базувалася на духовності та православній вірі. Однозначно, повернення педагогічної спадщини архієпископа Фаддея (Успенського) в скарбницю нашої педагогіки відчутно збагатило б останню: осмислена з точки зору сучасних виховних проблем, вона може позитивно впливати на їхнє практичне вирішення, особливо в царині підготовки сучасних жінок до духовно-морального виховання дітей. «Якщо багато педагогів стверджують, - наголошував Фаддей, - що виховання зобов'язане бути гуманним, то хто може бути більш гуманним християнина, який пройнятий любов’ю до всіх людей, як до братів у Христі, - не говорячи вже про те, що лише християнство може навчити істинної любові до всіх людей, не виключаючи ворогів» (Faddej, 1902).

\section{ЛІТЕРАТУРА:}

Нечаев П. Основные педагогические воззрения С. А. Рачинского. Народное образование. СПб. 1917. Т. І, Кн. 5-6, Май-июнь. С. 269-286.

Ольшевский И. (священник). Женские церковные школы и постановка в них учебновоспитательного дела. Полтава : Типо-Литография Л. Фришберга, 1897. 29 с

Самойлович И. Грамотность крестьянской женщини, как основа воспитания и скорейшего просвещения русского народа (С выяснением причин ничтожного процента грамотности среди женских полов крестьянского населения). К., 1901. 22 с.

Устав женских учебных заведений ведомства императрицы Марии, высочайше утвержденный 30.08.1855 г. Санкт-Петербург, 1884. 346 с.

Ушинський К.Д. Педагогічні ідеї. К.; 1971. 80 с.

Фаддей (Успенский И. В.). Записки по дидактике. Тверь, 2003. 335 с.

Фаддей (Успенский И. В.; иеромонах). Записки по дидактике. Уфа, 1902. 125 с.

\section{REFERENCES:}

Nechaev, P. (1917) Osnovnye pedagogicheskie vozzreniya S. A. Rachinskogo.[Basic pedagogical views of S. A. Rachinsky].Narodnoe obrazovanie, SPb. T. I, Kn. 5-6, Majiyun'. S. 269-286 (in Russian).

Ol'shevskij, I. (svyashchennik). (1897) Zhenskie cerkovnye shkoly i postanovka v nih uchebnovospitatel'nogo dela. [Women's church schools and the setting of educational work in them]. Poltava : Tipo-Litografiya L. Frishberga, 29 s. (in Russian).

Samojlovich, I. (1901) Gramotnost' krest'yanskoj zhenshchini, kak osnova vospitaniya i skorejshego prosveshcheniya russkogo naroda [The literacy of the peasant woman as the basis for the education and early enlightenment of the Russian people].(S vyyasneniem prichin nichtozhnogo procenta gramotnosti sredi zhenskih polov krest'yanskogo naseleniya). Kiev, 22 s. (in Russian).

Ustav zhenskih uchebnyh zavedenij vedomstva imperatricy Marii, vysochajshe utverzhdennyj $30.08 .1855 \mathrm{~g}$. [The Charter of the women's educational institutions of the Office of the 
Empress Maria, most highly approved on 30.08.1855]. (1884) Sankt-Peterburg, 346 s. (in Russian).

Ushins'kij, K. D. (1971) Pedagogichni ideï. [Pedagogical ideas]Kyiv, 80 s. (in Ukranian).

Faddej, (Uspenskij I. V.). (2003) Zapiski po didaktike. [Notes on didactics] Tver', 335 s. (in Russian).

Faddej, (Uspenskij I. V.; ieromonah). (1902) Zapiski po didaktike. [Notes on didactics] Ufa, 125 s. (in Russian).

\begin{tabular}{|c|c|}
\hline $\begin{array}{l}\text { Інформація про авторів: } \\
\text { Фазан Тетяна Павлівна: }\end{array}$ & $\begin{array}{l}\text { Information about the authors: } \\
\text { Fazan Tetiana Pavlivna: }\end{array}$ \\
\hline ORCID: $\quad$ https://orcid.org/0000-0001-9132- & https://orcid.org/0000-0001-9132- \\
\hline 9394, кандидат педагогічних наук, асистент & 9394, Candidate of Pedagogical Sciences, \\
\hline кафедри дошкільної освіти, Полтавський & Ph.D.,Assistant of the Department of Preschool \\
\hline національний педагогічний університет & Education, $\quad$ PoltavaV.G \\
\hline імені $\quad$ В. Г. Короленка, $\quad$ вул. & KorolenkoNationalPedagogicalUniversity, \\
\hline $\begin{array}{l}\text { Остроградського, 2, м. Полтава, Україна, } \\
36000\end{array}$ & Ostrohradskohost., 2, Poltava, Ukraine, 36000 \\
\hline e-mail: fazantp7@gmail.com & e-mail: fazantp7@gmail.com \\
\hline
\end{tabular}

Цитуйте цю статтю як: Фазан Т.П.Сутність та специфіка підготовки жінки до духовноморального виховання дітей (на основі праць святителя Фаддея Успенського).Теорія та методика навчання та виховання. 2021. № 50. С.174-183.

DOI: $10.34142 / 23128046.2021 .50 .16$

Дата надходження статті до редакції: 08.04.2021 p.

Стаття прийнята до друку: 16.04.2021 p. 